\title{
Design, Synthesis, in Vitro Antibacterial Activity, and Docking Studies of New Rhodanine Derivatives
}

\author{
Aisha Abusetta1, Jowhara Alumairi', Mariam Y. Alkaabi', Ruba Al Ajeil', Asma Abu Shkaidim¹, \\ Dana Akram', J. Pajak', Mohammad A. Ghattas ${ }^{2}$, Noor Atatreh², Shaikha S. Al Neyadi1* \\ ${ }^{1}$ Department of Chemistry, College of Science, UAE University, Al-Ain, UAE \\ ${ }^{2}$ College of Pharmacy, Al Ain University of Science and Technology, Al Ain, UAE \\ Email: *shaikha.alneyadi@uaeu.ac.ae
}

How to cite this paper: Abusetta, A., Alumairi, J., Alkaabi, M.Y., Al Ajeil, R., Shkaidim, A.A., Akram, D., Pajak, J., Ghattas, M.A., Atatreh, N. and Al Neyadi, S.S. (2020) Design, Synthesis, in Vitro Antibacterial Activity, and Docking Studies of New Rhodanine Derivatives. Open Journal of Medicinal Chemistry, 10, 15-34. https://doi.org/10.4236/ojmc.2020.101002

Received: February 10, 2020

Accepted: March 15, 2020

Published: March 18, 2020

Copyright $\odot 2020$ by author(s) and Scientific Research Publishing Inc. This work is licensed under the Creative Commons Attribution International License (CC BY 4.0).

http://creativecommons.org/licenses/by/4.0/

\begin{abstract}
Bacterial infections present a serious challenge to healthcare practitioners due to the emergence of resistance to numerous conventional antibacterial drugs. Therefore, new bacterial targets and new antimicrobials are unmet medical needs. Rhodanine derivatives are known to possess potent antimicrobial activities. In this study, we determined the activity spectrum of a series of new rhodanine derivatives against representative Gram-positive and Gram-negative bacterial strains. Compounds $\mathbf{3 a}$ and $\mathbf{5 a}$ had the highest activity with minimum inhibitory concentrations in the range of $1.12-2.5 \mu \mathrm{g} / \mathrm{mL}$. Transmission electron microscope results confirmed that activities against bacteria occurred via rupturing of the cell wall. Molecular modeling results suggested that rhodanine derivatives have the potential to irreversibly bind to the penicillin-binding protein (PBP) Ser62 residue in the active site. Thus, our results suggested that these rhodanine derivatives could be potential antibacterial drug candidates with strong activity against Gram-negative bacteria.
\end{abstract}

\section{Keywords}

Rhodanine Compounds, PBP, $\beta$-Lactamase Enzyme, Docking

\section{Introduction}

The treatment of bacterial infections has recently become a significant therapeutic challenge worldwide. Although effective antibiotics are still available for the most common infections, the emergence of multidrug-resistant bacterial pathogens and the spread of new infectious diseases threaten to undermine the effectiveness of the drugs currently approved for infectious disease therapy [1] [2]. 
Research on antibacterial compounds against Gram-positive and Gram-negative bacteria is facing a crisis. Whereas treatment options still exist for drug-resistant Gram-positive infections, the control of drug-resistant Gram-negative infections appears to be less effective since Gram-negative bacteria have a less permeable cell wall than Gram-positive bacteria [3]. The challenge of treating and eradicating certain infections is greatly increased by the lack of innovation in the development of new antibiotics, which led to a $60 \%$ decline in the number of new antibacterial drug approvals due to less identification of novel molecules with the desired activities [2]. Although this trend is changing, there is still an urgent need for the discovery of new antibacterial agents with divergent and unique structural features associated with mechanisms of action that differ from those of current antimicrobial agents [2].

Heterocyclic compounds are widely used in medicinal chemistry and play an important role in the search for new bioactive molecules in the pharmaceutical industry. Especially nitrogen-containing heterocycles appear to possess a diverse range of biological activities since they are found in many natural and synthetic molecules with known biological activities.

Rhodanine rings have been typically used as preferred scaffolds for the development of molecules with therapeutic potential. Rhodanines are five-membered heterocyclic compounds with a sulfur atom at position 1, a thiocarbonyl group at position 2, a nitrogen atom at position 3, and a carbonyl group at position 4 .

Rhodanine compounds are of significant interest for medicinal chemists because their wide range of biological properties includes antibacterial [4], antifungal [5], antidiabetic [6], anti-inflammatory [7], antituberculosis [8], anticancer [9], anti-HIV [10], antiparasitic [11], hypnotic [12], and anthelmintic [13] activities.

In this study, we designed and synthesized new rhodanine compounds using a simple and efficient method for creating new molecules with potentially significant antibacterial activity. The compound structures were determined using elemental analysis, along with Fourier-transform infrared spectroscopy (FTIR) and 1D-NMR spectral data. The initial screening for antimicrobial activity was based on the well diffusion method, which measured the diameter (in $\mathrm{mm}$ ) of the growth inhibition zone formed around a well loaded with a test compound that was made on an agar plate inoculated with bacteria. Compounds that were active in the well diffusion test were then assayed for the minimum inhibitory concentration (MIC). We further performed a structure-activity relationship (SAR) analysis of several rhodanine compounds. We also explored potential mechanisms involved in the antimicrobial activity of rhodanine compounds by examining the mode of interaction with penicillin-binding protein using molecular modeling and transmission electron microscopy (TEM).

\section{Material and Methods}

\subsection{Chemistry}

All reagents and chemicals were purchased from Sigma-Aldrich (St. Louis, MO) and used without further purification. Thin-layer chromatography (TLC) was 
performed on silica gel glass plates (Silica gel, $60 \mathrm{~F}_{254}$, Fluka) and the spots were visualized under a UV lamp. Column chromatography was performed on a silica gel (silica gel S, $0.063-0.1 \mathrm{~mm}$ ). The melting points were recorded on a Gallenkamp apparatus and were uncorrected. Infrared spectra were measured with a Thermo Nicolet 470 FT-IR spectrophotometer using $\mathrm{KBr}$ pellets. ${ }^{1} \mathrm{H}-\mathrm{NMR}$ spectra were recorded with a $400 \mathrm{MHz}$ Varian NMR spectrometer using DMSO- $d_{6}$ and $\mathrm{CDCl}_{3}$ solutions and tetramethylsilane (TMS) as an internal reference. The elemental analysis was performed using a Leco CHN-600 elemental analyzer. Microwave synthetic protocol was implemented using a CEM Microwave synthesis system. UV-vis absorption spectra were collected on a UV-1800 spectrophotometer (Shimadzu, Japan) in $1 \mathrm{~cm}$ quartz cell at room temperature.

\section{Synthesis of 2-(4'-Oxo-2'-thioxothiazolidin-3'-yl)acetic acid 2}

This compound was synthesized as reported previously [14]. Briefly, rhodanine $(0.02 \mathrm{~mol}, 4.78 \mathrm{~g})$ was dissolved in $50 \mathrm{ml}$ of dry toluene. The solution was cooled to $15^{\circ} \mathrm{C}$, and chloroacetic acid $(0.05 \mathrm{M} ; 5.2 \mathrm{~g}$ in $10 \mathrm{ml}$ of water) was added dropwise. Then, the mixture stirred at $40^{\circ} \mathrm{C}$ for $24 \mathrm{~h}$, and the excess of toluene was removed under reduced pressure. The solid was recovered and recrystallized to obtain 3 . Pale yellow powder, yield $81 \%$; mp $145^{\circ} \mathrm{C}-148^{\circ} \mathrm{C}$; ${ }^{1} \mathrm{H}-\mathrm{NMR}$ [DMSO- $d_{6}, 400 \mathrm{MHz}$ ]: $(\delta, p p m) 4.35$ (s, $2 \mathrm{H}, \mathrm{CH}_{2}$, rhodanine), 4.53 (s, $2 \mathrm{H}, \mathrm{CH}_{2}$, acetyl), 7.84 (brs, $1 \mathrm{H}, \mathrm{OH}$, exchanges with $\mathrm{D}_{2} \mathrm{O}$ ); ${ }^{13} \mathrm{C}-\mathrm{NMR}$ [DMSO- $d_{6}$, $100 \mathrm{MHz}$ : $(\delta, \mathrm{ppm}) 36.5$ (C5-rhodanine), $45.2\left(\mathrm{CH}_{2}\right.$, acetyl group), 167.8 $(\mathrm{COOH}), 174.2(\mathrm{C}=\mathrm{O}), 172.3(\mathrm{C}=\mathrm{O}), 203.2(\mathrm{C}=\mathrm{S})$.

\section{General Synthetic Procedure for Preparation of Compounds 3a-g}

To a solution of aldehyde derivative $(0.10 \mathrm{mmol}, 1.0$ equiv. $)$ and rhodanine acetic acid $(0.10 \mathrm{mmol}, 1.0$ equiv. $)$ in dry $\mathrm{CH}_{2} \mathrm{Cl}_{2}(10.0 \mathrm{ml})$ in a $35 \mathrm{ml} \mathrm{CEM} \mathrm{Mi}-$ crowave vial, an aliquot of piperidine $(0.20 \mathrm{mmol}, 0.2 \mathrm{ml})$ was added. The reaction mixture was heated under microwave irradiation $\left(100^{\circ} \mathrm{C}\right)$ for $2-3 \mathrm{~min}$. The progress of the reaction was monitored by TLC. After completion, the formed precipitate was filtered and recrystallized from an acetone/water (2:1) mixture.

(Z)-2-(4-oxo-5-(pyrazolo[1,5-a]pyrimidin-6-ylmethylene)-2-thioxothiazo lidin-3-yl)acetic acid (3a): Light green powder; yield $94 \%$; $\mathrm{mp} 228^{\circ} \mathrm{C} ; \mathrm{R}_{f} 0.43$; IR $\left(\mathrm{KBr}, \mathrm{cm}^{-1}\right)$ : $2949(\mathrm{C}-\mathrm{H}), 1723,1622(\mathrm{C}=\mathrm{O}), 1520(\mathrm{C}=\mathrm{C}), 1194(\mathrm{C}=\mathrm{S})$; ${ }^{1} \mathrm{H}-\mathrm{NMR}$ [DMSO- $d_{6}, 400 \mathrm{MHz}$ ] $(\delta, p p m) 4.38\left(\mathrm{~s}, 2 \mathrm{H}, \mathrm{CH}_{2}\right), 6.50\left(\mathrm{~d}\right.$, pyrazole- $\mathrm{H}_{4}$, $J=8.0 \mathrm{~Hz}), 7.35\left(\mathrm{~d}\right.$, pyrazole $\left.-\mathrm{H}_{3}, J=8.0 \mathrm{~Hz}\right), 7.91(\mathrm{~s}, 1 \mathrm{H}$, olefinic $\mathrm{H}), 8.83(\mathrm{~s}, 2 \mathrm{H}$, $\mathrm{H}_{4,6}$-pyrimidine), 12.68 (brs, $1 \mathrm{H}, \mathrm{OH}$, exchanges with $\mathrm{D}_{2} \mathrm{O}$ ); ${ }^{13} \mathrm{C}$-NMR [DMSO- $d_{6}$, $100 \mathrm{MHz}$ : $(\delta, \mathrm{ppm}) 48.1\left(\mathrm{CH}_{2}\right), 105.9$ (C4-pyrazole), 111.8 (C5-rhodanine), 118.6 (C5-pyrimidine), 122.7 (C4-pyrimidine), 138.1 (olefinic C), 146.6 (C3pyrazole), 146.8 (C2-pyrimidine), 153.4 (C6-pyrimidine), $167.3(\mathrm{C}=\mathrm{O}), 168.5$ $(\mathrm{C}=\mathrm{O}, \mathrm{COOH}), 193.9(\mathrm{~S}=\mathrm{O})$; analysis calculated for $\mathrm{C}_{12} \mathrm{H}_{8} \mathrm{~N}_{4} \mathrm{O}_{3} \mathrm{~S}_{2}: \mathrm{C}, 44.99 ; \mathrm{H}$, 2.52; N, 17.49; O, 14.98; S, 20.02; analysis results: C, 45.29; H, 2.82; N, 17.79; S, 20.32 .

(Z)-2-(5-(4-hydroxy-3-methoxybenzylidene)-4-oxo-2-thioxothiazolidin-3- 
yl)acetic acid (3b): Yellow powder, yield $92 \%$; $m p 233^{\circ} \mathrm{C} ; \mathrm{R}_{f} 0.50$; IR $(\mathrm{KBr}$, $\left.\mathrm{cm}^{-1}\right)$ : $2953(\mathrm{C}-\mathrm{H}), 1712,1641(\mathrm{C}=\mathrm{O}), 1514(\mathrm{C}=\mathrm{C}), 1204(\mathrm{C}=\mathrm{S})$; ${ }^{1} \mathrm{H}-\mathrm{NMR}$ [DMSO- $\left.d_{6}, 400 \mathrm{MHz}\right]:(\delta, p p m) 2.91\left(\mathrm{~s}, 3 \mathrm{H}, \mathrm{OCH}_{3}\right), 4.37\left(\mathrm{~s}, 2 \mathrm{H}, \mathrm{CH}_{2}\right), 6.94-7.10$ $(\mathrm{m}, 3 \mathrm{H}$, aromatic $\mathrm{H}), 7.69$ (s, $1 \mathrm{H}$, olefinic $\mathrm{H}$ ), 9.68 ( brs, $1 \mathrm{H}, \mathrm{OH}$, exchanges with $\mathrm{D}_{2} \mathrm{O}$ ), 12.60 (brs, $1 \mathrm{H}, \mathrm{OH}, \quad \mathrm{COOH}$, exchanges with $\mathrm{D}_{2} \mathrm{O}$ ); ${ }^{13} \mathrm{C}$-NMR [DMSO- $d_{6}$, $100 \mathrm{MHz}$ : ( $\delta$, ppm) $48.2\left(\mathrm{CH}_{2}\right), 56.0\left(\mathrm{CH}_{3}\right), 114.8$ (aromatic C), 116.9 (C5-rhodanine), 118.3 (aromatic C), 124.5 (aromatic C), 125.8 (aromatic C), 134.1 (olefinic C), 148.7 (aromatic C), 151.4 (aromatic C), $167.4(\mathrm{C}=\mathrm{O}), 167.9(\mathrm{C}=\mathrm{O}$, $\mathrm{COOH}), 193.4(\mathrm{~S}=\mathrm{O})$; analysis calculated for $\mathrm{C}_{13} \mathrm{H}_{11} \mathrm{NO}_{5} \mathrm{~S}_{2}: \mathrm{C}, 47.99 ; \mathrm{H}, 3.41 ; \mathrm{N}$, 4.31; O, 24.59; S, 19.71; analysis results: C, 48.32; H, 3.61; N, 4.60; S, 20.01.

(Z)-2-(5-(4-formylbenzylidene)-4-oxo-2-thioxothiazolidin-3-yl)acetic acid

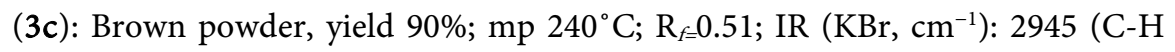
aliphatic), 1719 (C=O, CHO), 1639,1599 (C=O), $1508(\mathrm{C}=\mathrm{N}), 1190(\mathrm{C}=\mathrm{S})$; ${ }^{1} \mathrm{H}-\mathrm{NMR}$ [DMSO- $d_{\sigma}, 400 \mathrm{MHz}$ ]: $(\delta, p p m) 4.45\left(\mathrm{~s}, 6 \mathrm{H}, \mathrm{CH}_{3}\right), 7.55(2 \mathrm{H}$, aromatic $\mathrm{H}), 7.88(2 \mathrm{H}$, aromatic $\mathrm{H}), 8.00(\mathrm{~s}, 1 \mathrm{H}$, olefinic $\mathrm{H}), 8.89$ ( s, $\mathrm{IH}, \mathrm{CHO}), 12.70$ (brs, $1 \mathrm{H}, \mathrm{OH}$, exchanges with $\left.\mathrm{D}_{2} \mathrm{O}\right) ;{ }^{13} \mathrm{C}-\mathrm{NMR}$ [DMSO- $d_{6}, 100 \mathrm{MHz}$ ]: $(\delta, p p m)$ $43.9\left(\mathrm{CH}_{3}\right), 115.3$ (C5-rhodanine), 117.4 (aromatic C), 118.7 (aromatic $\left.\mathrm{C}\right), 134.5$ (aromatic C), 141.1 (aromatic C), 144.2 (olefinic $\mathrm{C}), 156.3(\mathrm{C}=\mathrm{O}), 169.2(\mathrm{C}=\mathrm{O}$, $\mathrm{COOH}), 191.0(\mathrm{C}=\mathrm{O}, \mathrm{CHO}), 194.7(\mathrm{C}=\mathrm{S})$; analysis calculated for $\mathrm{C}_{13} \mathrm{H}_{9} \mathrm{NO}_{4} \mathrm{~S}_{2}: \mathrm{C}$, 50.80; H, 2.95; N, 4.56; O, 20.82; S, 20.86; analysis results: C, 51.11; H, 3.01; N, 5.02; S, 21.16 .

(Z)-2-(5-(4-fluorobenzylidene)-4-oxo-2-thioxothiazolidin-3-yl)acetic acid (3d): Yellow powder, yield $85 \%$; $\mathrm{mp} 262^{\circ} \mathrm{C}$; $\mathrm{R}_{f} \quad 0.40 ; \mathrm{IR}\left(\mathrm{KBr}, \mathrm{cm}^{-1}\right): 3375(\mathrm{OH})$, 2950 (C-H aliphatic), 1697,1634 (C=O), $1592(\mathrm{C}=\mathrm{C}), 1291(\mathrm{C}=\mathrm{S}) ;{ }^{1} \mathrm{H}-\mathrm{NMR}$ [DMSO- $d_{6}, 400 \mathrm{MHz}$ : $(\delta, p p m) 4.36\left(\mathrm{~s}, 2 \mathrm{H}, \mathrm{CH}_{2}\right), 7.40$ (d, 2H, aromatic), 7.72 (d, $2 \mathrm{H}$, aromatic), 7.81 (s, $1 \mathrm{H}$, olefinic $\mathrm{H}$ ), 12.60 (brs, $1 \mathrm{H}, \mathrm{OH}$, exchanges with $\left.\mathrm{D}_{2} \mathrm{O}\right) ;{ }^{13} \mathrm{C}-\mathrm{NMR}$ [DMSO- $d_{6}, 100 \mathrm{MHz}$ ]: $(\delta, p p m) 48.3\left(\mathrm{CH}_{2}\right), 117.0$ (aromatic C), 117.3 (C5-rhodanine), 122.8 (aromatic C), 130.2 (aromatic C), 131.8 (olefinic C), 133.5 (aromatic $\mathrm{C}), 167.2(\mathrm{C}=\mathrm{O}), 167.8(\mathrm{C}=\mathrm{O}, \mathrm{COOH}), 193.5(\mathrm{C}=\mathrm{S})$; analysis calculated for $\mathrm{C}_{12} \mathrm{H}_{8} \mathrm{FNO}_{3} \mathrm{~S}_{2}$ : C, 48.48; H, 2.71; F, 6.39; N, 4.71; O, 16.14; S, 21.57; analysis results: $\mathrm{C}, 48.81 ; \mathrm{H}, 3.04 ; \mathrm{N}, 5.01 ; \mathrm{S}, 21.87$.

(Z)-2-[2'-(Dimethylamino)pyrimidin-5'-yl)methylene)-4-oxo-2-thioxothi azolidin-3-yl]acetic acid (3e): Yellow powder, yield $81 \%$; mp $234^{\circ} \mathrm{C}$; IR $(\mathrm{KBr}$, $\left.\mathrm{cm}^{-1}\right)$ : $3290(\mathrm{OH}), 3048(\mathrm{C}-\mathrm{H}$, aromatic), 2936 (aliphatic C-H), $1705(\mathrm{C}=\mathrm{O})$, $1409(\mathrm{C}=\mathrm{N}) ;{ }^{1} \mathrm{H}-\mathrm{NMR}$ [DMSO- $d_{\sigma}, 400 \mathrm{MHz}$ ]: $(\delta, p p m) 3.19\left(\mathrm{~s}, 6 \mathrm{H}, \mathrm{CH}_{3}\right), 4.33$ ( s, $2 \mathrm{H}, \mathrm{CH}_{2}$ ), 7.61 (s, $1 \mathrm{H}$, olefinic $\mathrm{H}$ ), 8.58 (s, $2 \mathrm{H}, \mathrm{H}_{4,6}$-pyrimidine), 9.60 (brs, $1 \mathrm{H}, \mathrm{OH}$, exchanges with $\left.\mathrm{D}_{2} \mathrm{O}\right) ;{ }^{13} \mathrm{C}-\mathrm{NMR}$ [DMSO- $d_{6}, 100 \mathrm{MHz}$ ]: $(\delta, p p m) 43.8$ $\left(\mathrm{CH}_{3}\right), 48.4\left(\mathrm{CH}_{2}\right), 115.9$ (C5-pyrimidine), 118.1 (C5-rhodanine), 128.7 (olefinic C), 160.3 (C4,6-pyrimidine), 160.8 (C2-pyrimidine) $167.1(\mathrm{C}=\mathrm{O}), 167.8(\mathrm{C}=\mathrm{O}$, carboxlic acid), $192.7(\mathrm{C}=\mathrm{S})$; analysis calculated for $\mathrm{C}_{12} \mathrm{H}_{12} \mathrm{~N}_{4} \mathrm{O}_{3} \mathrm{~S}_{2}: \mathrm{C}, 44.43 ; \mathrm{H}$, 3.73; N, 17.27; S, 19.77; analysis results: C, 44.88; H, 3.80; N, 17.55; S, 20.05; analysis calculated for $\mathrm{C}_{12} \mathrm{H}_{12} \mathrm{~N}_{4} \mathrm{O}_{3} \mathrm{~S}_{2}$. $\mathrm{CH}_{3} \mathrm{I}$ : C, 33.48; $\mathrm{H}, 3.24 ; \mathrm{N}, 12.01 ; \mathrm{S}, 13.75$; analysis results: $\mathrm{C}, 33.67 ; \mathrm{H}, 3.03 ; \mathrm{N}, 12.03 ; \mathrm{S}, 13.77$. 
(Z)-2-[5'-(2"-Morpholinopyrimidin-5"'-yl)methylene)-4'-oxo-2'-thioxothi azolidin-3'-yl]acetic acid (3f): Yellow powder, yield $88 \%$; mp $248^{\circ} \mathrm{C}$; IR $(\mathrm{KBr}$, $\left.\mathrm{cm}^{-1}\right)$ : $3590(\mathrm{OH}), 3058(\mathrm{C}-\mathrm{H}$, aromatic), 2960 (aliphatic C-H), $1713(\mathrm{C}=\mathrm{O})$, $1508(\mathrm{C}=\mathrm{N}) ;{ }^{1} \mathrm{H}-\mathrm{NMR}$ [DMSO- $d_{6}, 400 \mathrm{MHz}$ ]: $(\delta, p p m)$ 3.64-3.65 (m, 4H, morpholine), 3.81-3.83 (m, $4 \mathrm{H}$, morpholine), $4.32\left(\mathrm{~s}, 2 \mathrm{H}, \mathrm{CH}_{2}\right), 7.64(\mathrm{~s}, 1 \mathrm{H}$, olefinic $\mathrm{H}$ ), 8.63 (s, 2H, $\mathrm{H}_{4,6}$-pyrimidine), 11.78 (brs, $1 \mathrm{H}, \mathrm{OH}$, exchanges with $\left.\mathrm{D}_{2} \mathrm{O}\right) ;{ }^{13} \mathrm{C}-\mathrm{NMR}$ [DMSO- $d_{6}, 100 \mathrm{MHz}$ ]: $(\delta$, ppm $) 44.5\left(\mathrm{CH}_{2}\right), 48.4,66.3$ ( morpholine), 116.8 (C5-pyrimidine), 119.1 (C5-rhodanine), 128.2 (olefinic $\mathrm{C}$ ), 160.2 (C4,6- pyrimidine), 160.4 (C2-pyrimidine), $167.0(\mathrm{C}=\mathrm{O}), 167.1(\mathrm{C}=\mathrm{O}$, carboxlic acid), $192.7(\mathrm{C}=\mathrm{S})$; analysis calculated for $\mathrm{C}_{14} \mathrm{H}_{14} \mathrm{~N}_{4} \mathrm{O}_{4} \mathrm{~S}_{2}: \mathrm{C}, 45.89 ; \mathrm{H}$, 3.85; N, 15.29; S, 17.50; analysis results: $\mathrm{C}, 46.34 ; \mathrm{H}, 3.92 ; \mathrm{N}, 15.57$; $\mathrm{S}, 17.78$; analysis calculated for $\mathrm{C}_{14} \mathrm{H}_{14} \mathrm{~N}_{4} \mathrm{O}_{4} \mathrm{~S}_{2}$. $\mathrm{CH}_{3} \mathrm{I}$ : C, 35.44; $\mathrm{H}, 3.37$; N, 11.02; S, 12.62; analysis results: $\mathrm{C}, 35.63 ; \mathrm{H}, 3.18 ; \mathrm{N}, 11.05 ; \mathrm{S}, 12.64$.

(Z)-2-[5'-(2"-(Isopropylamino)pyrimidin-5"'-yl)methylene)-4'-oxo-2'-thi oxothiazolidin-3'-yl]acetic acid (3g): Yellow powder, yield $86 \%$; $\mathrm{mp} 257^{\circ} \mathrm{C}$; IR $\left(\mathrm{KBr}, \mathrm{cm}^{-1}\right): 3442(\mathrm{OH}), 3242(\mathrm{NH}), 3080(\mathrm{C}-\mathrm{H}$, aromatic), 2865 (aliphatic $\mathrm{C}-\mathrm{H})$, $1716(\mathrm{C}=\mathrm{O}), 1448(\mathrm{C}=\mathrm{N})$; ${ }^{1} \mathrm{H}-\mathrm{NMR}$ [DMSO- $d_{6}, 400 \mathrm{MHz}$ : $(\delta, p p m) 1.19(\mathrm{~s}, 6 \mathrm{H}$, $\mathrm{CH}_{3}$, isopropyl group), $4.12-4.17$ (m, $\mathrm{CH}$-isopropyl group), 4.39 (s, $1 \mathrm{H}, \mathrm{CH}_{2}$, rhodanine), $7.62(\mathrm{~s}, 1 \mathrm{H}$, olefinic $\mathrm{H}), 8.13(\mathrm{~d}, 1 \mathrm{H}, \mathrm{NH}, J=6.0 \mathrm{~Hz}), 8.58(\mathrm{~s}, 2 \mathrm{H}$, $\mathrm{H}_{4,6}$-pyrimidine), 11.04 (brs, $1 \mathrm{H}, \mathrm{OH}$, exchanges with $\mathrm{D}_{2} \mathrm{O}$ ); ${ }^{13} \mathrm{C}-\mathrm{NMR}$ [DMSO- $d_{\sigma}, 100 \mathrm{MHz}$ ]: $(\delta, \mathrm{ppm}) 22.6\left(\mathrm{CH}_{3}\right.$, isopropyl), $43.9(\mathrm{CH}$, isopropyl), 45.4 ( $\mathrm{CH}_{2}$, rhodanine), 116.4 (C5-pyrimidine), 117.6 (C5-rhodanine), 129.1 (olefinic C), 160.3 (C4,6-pyrimidine), 160.9 (C2-pyrimidine) 167.1 (C=O), $167.2(\mathrm{C}=\mathrm{O}$, carboxlic acid), $192.7\left(\mathrm{C}=\mathrm{S}\right.$ ); analysis calculated for $\mathrm{C}_{13} \mathrm{H}_{14} \mathrm{~N}_{4} \mathrm{O}_{3} \mathrm{~S}_{2}: \mathrm{C}, 46.14 ; \mathrm{H}$, 4.17; N, 16.56; S, 18.95; analysis results: $\mathrm{C}, 46.59 ; \mathrm{H}, 4.24 ; \mathrm{N}, 16.84 ; \mathrm{S}, 19.23$; analysis calculated for $\mathrm{C}_{13} \mathrm{H}_{14} \mathrm{~N}_{4} \mathrm{O}_{3} \mathrm{~S}_{2} . \mathrm{C}_{4} \mathrm{H}_{6} \mathrm{O}_{6}$ : $\mathrm{C}, 41.80 ; \mathrm{H}, 4.13 ; \mathrm{N}, 11.47 ; \mathrm{S}, 13.13$; analysis results: $\mathrm{C}, 41.99 ; \mathrm{H}, 3.93$; N, 11.48; $\mathrm{S}, 13.15$.

\section{General Synthetic Procedure for Preparation of Compounds 5a-f}

A solution of $0.7 \mathrm{~mL}$ of concentrated ammonia ( $0.7 \mathrm{~g}$ of ammonium chloride dissolved in $2 \mathrm{~mL}$ of water) with $0.009 \mathrm{~mol}$ of the appropriate aldehyde was added rapidly under stirring to a hot suspension of $0.009 \mathrm{~mol}$ of 3-aminorhodanine in $15 \mathrm{ml}$ of ethanol. The mixture was refluxed for $2 \mathrm{~h}$ and transferred to a $35 \mathrm{ml}$ CEM Microwave vial. Then, the reaction mixture was heated under microwave irradiation $\left(150^{\circ} \mathrm{C}\right)$ for $5 \mathrm{~min}$. The progress of the reaction was monitored by TLC. After completion, the formed precipitate was filtered, washed with $50 \mathrm{~mL}$ of water, followed with $50 \mathrm{~mL}$ of ethanol diluted in water $(1: 1, \mathrm{v} / \mathrm{v})$, and recrystallized from acetone.

(Z)-3-amino-5-(pyrazolo[1,5-a]pyrimidin-6-ylmethylene)-2-thioxothiazo lidin-4-one (5a): Yellow powder, yield $90 \%$; $\mathrm{mp} 269^{\circ} \mathrm{C}$; $\mathrm{IR}\left(\mathrm{KBr}, \mathrm{cm}^{-1}\right)$ : 3266, $3279\left(\mathrm{NH}_{2}\right), 1704(\mathrm{C}=\mathrm{O}), 1616(\mathrm{C}=\mathrm{C}), 1529(\mathrm{C}=\mathrm{N}), 1245(\mathrm{C}=\mathrm{S}) ;{ }^{1} \mathrm{H}-\mathrm{NMR}$ [DMSO- $d_{6}, 400 \mathrm{MHz}$ ]: $(\delta, p p m) 5.95\left(\mathrm{~s}, 2 \mathrm{H}, \mathrm{NH}_{2}\right.$ exchanges with $\left.\mathrm{D}_{2} \mathrm{O}\right), 7.12(\mathrm{~d}$, pyrazole- $\left.\mathrm{H}_{4}\right), 7.34\left(\mathrm{~d}\right.$, pyrazole- $\left.\mathrm{H}_{3}\right), 7.97(\mathrm{~s}, 1 \mathrm{H}$, olefinic $\mathrm{H}), 8.64\left(\mathrm{~s}, \mathrm{H}_{4,6}-\right.$ pyrimidine); ${ }^{13} \mathrm{C}-\mathrm{NMR}$ [DMSO- $d_{\sigma}, 100 \mathrm{MHz}$ ]: $(\delta, \mathrm{ppm}) 109.9$ (C4-pyrazole), 124.0 (C5-rhodanine), 133.9 (C5-pyrimidine), 137.3 (C4-pyrimidine), 138.1 (olefinic 
C), 143.1 (C3-pyrazole), 146.8 (C2-pyrimidine), 151.9 (C6-pyrimidine), 153.5 $(\mathrm{C}=\mathrm{O}), 177.6(\mathrm{~S}=\mathrm{O})$; analysis calculated for $\mathrm{C}_{10} \mathrm{H}_{7} \mathrm{~N}_{5} \mathrm{OS}_{2}: \mathrm{C}, 43.31 ; \mathrm{H}, 2.54 ; \mathrm{N}$, 25.25; O, 5.77; S, 23.12; analysis results: $\mathrm{C}, 43.60 ; \mathrm{H}, 2.82 ; \mathrm{N}, 25.54 ; \mathrm{S}, 23.42$.

(Z)-3-amino-5-((2-(dimethylamino)pyrimidin-5-yl)methylene)-2-thioxot hiazolidin-4-one (5b): Light green powder, yield $93 \%$; mp $230^{\circ} \mathrm{C}$; IR $(\mathrm{KBr}$, $\left.\mathrm{cm}^{-1}\right)$ : 3275, $3153\left(\mathrm{NH}_{2}\right), 2947$ (C-H aliphatic), $1699(\mathrm{C}=\mathrm{O}), 1592(\mathrm{C}=\mathrm{C}), 1199$ $(\mathrm{C}=\mathrm{S}) ;{ }^{1} \mathrm{H}-\mathrm{NMR}$ [DMSO- $d_{6}, 400 \mathrm{MHz}$ : $(\delta, p p m) 3.20\left(\mathrm{~s}, 6 \mathrm{H}, 2 \mathrm{CH}_{3}\right), 5.94(\mathrm{~s}, 2 \mathrm{H}$, $\mathrm{NH}_{2}$ exchanges with $\mathrm{D}_{2} \mathrm{O}$ ), 7.67 (s, $1 \mathrm{H}$, olefinic $\mathrm{H}$ ), 8.59 (s, $2 \mathrm{H}, \mathrm{H}_{4,6}$-pyrimidine); ${ }^{13} \mathrm{C}-\mathrm{NMR}$ [DMSO- $d_{6}, 100 \mathrm{MHz}$ ]: $(\delta, p p m) 37.3\left(\mathrm{CH}_{3}\right), 115.4$ (C5-pyrimidine), 115.8 (C5-rhodanine), 129.9 (olefinic $\mathrm{C}), 157.4\left(\mathrm{C}_{4,6}\right.$-pyrimidine), $160.6(\mathrm{C}=\mathrm{O})$, 164.0 (C2-pyrimidine), $186.8(\mathrm{~S}=\mathrm{O})$; analysis calculated for $\mathrm{C}_{10} \mathrm{H}_{11} \mathrm{~N}_{5} \mathrm{OS}_{2}$ : C, 42.69; H, 3.94; N, 24.89; O, 5.69; S, 22.79; analysis results: C, 42.99; H, 4.24; N, 25.18; S, 23.09 .

Methyl (Z)-4-((3-amino-4-oxo-2-thioxothiazolidin-5-ylidene)methyl)benzoat (5c): Light green powder, yield $89 \%$; mp $240^{\circ} \mathrm{C}$; $\mathrm{IR}\left(\mathrm{KBr}, \mathrm{cm}^{-1}\right): 3442\left(\mathrm{NH}_{2}\right)$, 2924 (C-H aliphatic), 1703 (C=O), 1589 (C=C), 1189 (C=S); ${ }^{1} \mathrm{H}-\mathrm{NMR}$ [DMSO- $d_{6}, 400 \mathrm{MHz}$ ]: $(\delta, p p m) 3.20\left(\mathrm{~s}, 6 \mathrm{H}, 2 \mathrm{CH}_{3}\right), 6.97(\mathrm{~m}, 1 \mathrm{H}$, aromatic- $\mathrm{H})$, $7.51(\mathrm{~m}, 1 \mathrm{H}$, aromatic- $\mathrm{H}), 7.66(\mathrm{~m}, 2 \mathrm{H}$, aromatic- $\mathrm{H}), 7.68(\mathrm{~s}, 1 \mathrm{H}$, olefinic $\mathrm{H})$, $8.02\left(\mathrm{~s}, 2 \mathrm{H}, \mathrm{NH}_{2}\right.$ exchanges with $\left.\mathrm{D}_{2} \mathrm{O}\right) ;{ }^{13} \mathrm{C}-\mathrm{NMR}$ [DMSO- $d_{6}, 100 \mathrm{MHz}$ ]: $(\delta$, ppm) $52.8\left(\mathrm{CH}_{3}\right), 128.4$ (C5-rhodanine), 130.3 - 131.0 (aromatic $\mathrm{C}$ ), 138.3 (olefinic $\mathrm{C}), 166.0(\mathrm{C}=\mathrm{O}), 173.0(\mathrm{C}=\mathrm{O}$, ester), $197.6(\mathrm{C}=\mathrm{S})$; analysis calculated for $\mathrm{C}_{12} \mathrm{H}_{10} \mathrm{~N}_{2} \mathrm{O}_{3} \mathrm{~S}_{2}$ : C, 48.97; $\mathrm{H}, 3.42 ; \mathrm{N}, 9.52 ; \mathrm{O}, 16.31 ; \mathrm{S}, 21.78$; analysis results: $\mathrm{C}$, $50.20 ; \mathrm{H}, 3.72 ; \mathrm{N}, 9.80 ; \mathrm{S}, 22.08$.

(E)-3-amino-5-((Z)-3-phenylallylidene)-2-thioxothiazolidin-4-one (5d): Yellow powder, yield 91\%; mp $226^{\circ} \mathrm{C}$; IR $\left(\mathrm{KBr}, \mathrm{cm}^{-1}\right): 3415\left(\mathrm{NH}_{2}\right), 1703(\mathrm{C}=\mathrm{O})$, $1578(\mathrm{C}=\mathrm{C}), 1126(\mathrm{C}=\mathrm{S}) ;{ }^{1} \mathrm{H}-\mathrm{NMR}$ [DMSO- $d_{6}, 400 \mathrm{MHz}$ : $(\delta, p p m) 5.92$ (brs, $2 \mathrm{H}, \mathrm{NH}_{2}$ exchanges with $\left.\mathrm{D}_{2} \mathrm{O}\right), 7.80(\mathrm{~m}, 1 \mathrm{H}$, olefinic $\mathrm{H}), 7.41-7.44(\mathrm{~m}, 4 \mathrm{H}$, aromatic), $7.57(\mathrm{~m}, 1 \mathrm{H}$, olefinic $\mathrm{H}), 7.70(\mathrm{~m}, 1 \mathrm{H}$, olefinic $\mathrm{H}) ;{ }^{13} \mathrm{C}-\mathrm{NMR}$ [DMSO- $d_{6}$, $100 \mathrm{MHz}$ : ( $\delta$, ppm) 121.9 (C5-rhodanine), 123.8 (olefinic C), 128.6 - 134.4 (aromatic C), 135.9 (olefinic C), 145.9 (olefinic C), $163.5(\mathrm{C}=\mathrm{O}), 187.7(\mathrm{C}=\mathrm{S})$; analysis calculated for $\mathrm{C}_{12} \mathrm{H}_{10} \mathrm{~N}_{2} \mathrm{OS}_{2}$ : $\mathrm{C}, 54.94 ; \mathrm{H}, 3.84 ; \mathrm{N}, 10.68 ; \mathrm{O}, 6.10 ; \mathrm{S}, 24.44$; analysis results: $\mathrm{C}, 55.22 ; \mathrm{H}, 4.01 ; \mathrm{N}, 10.97 ; \mathrm{S}, 24.73$.

(Z)-3-amino-5-(4-methoxybenzylidene)-2-thioxothiazolidin-4-one (5e): Light brown powder, yield 94\%; mp $270^{\circ} \mathrm{C}$; IR $\left(\mathrm{KBr}, \mathrm{cm}^{-1}\right): 3586\left(\mathrm{NH}_{2}\right), 2980$ (C-H aliphatic), $1730(\mathrm{C}=\mathrm{O}), 1586(\mathrm{C}=\mathrm{C}), 1238(\mathrm{C}=\mathrm{S}) ;{ }^{1} \mathrm{H}-\mathrm{NMR}$ [DMSO- $d_{6}, 400$ $\mathrm{MHz}$ : $(\delta, p p m) 3.80\left(\mathrm{~s}, 3 \mathrm{H}, \mathrm{CH}_{3}\right), 5.93$ (brs, $2 \mathrm{H}, \mathrm{NH}_{2}$, exchanges with $\left.\mathrm{D}_{2} \mathrm{O}\right), 6.92$ $(\mathrm{d}, 2 \mathrm{H}$, aromatic, $J=8.0 \mathrm{~Hz}), 7.51(\mathrm{~d}, 2 \mathrm{H}$, aromatic, $J=8.0 \mathrm{~Hz}), 7.76(\mathrm{~s}, 1 \mathrm{H}$, olefinic H); ${ }^{13} \mathrm{C}-\mathrm{NMR}$ [DMSO- $d_{6}, 100 \mathrm{MHz}$ ]: $(\delta, p p m) 55.6\left(\mathrm{CH}_{3}\right), 115.9$ (aromatic C), 117.1(C5-rhodanine), 124.5 - 133.9 (aromatic C), 134.6 (olefinic C), 161.2 (aromatic $\mathrm{C}), 164.3(\mathrm{C}=\mathrm{O}), 187.6(\mathrm{C}=\mathrm{S})$; analysis calculated for $\mathrm{C}_{11} \mathrm{H}_{10} \mathrm{~N}_{2} \mathrm{O}_{2} \mathrm{~S}_{2}$ : C, 49.61; H, 3.78; N, 10.52; O, 12.01; S, 24.08; analysis results: C, $49.90 ; \mathrm{H}, 4.08 ; \mathrm{N}, 10.80 ; \mathrm{S}, 24.37$.

(Z)-3-amino-5-(4-nitrobenzylidene)-2-thioxothiazolidin-4-one (5f): Light brown powder, yield 92\%; mp $245^{\circ} \mathrm{C}$; IR $\left(\mathrm{KBr}, \mathrm{cm}^{-1}\right)$ : 3245, $3160\left(\mathrm{NH}_{2}\right), 2973$ 
(C-H aliphatic), $1602(\mathrm{C}=\mathrm{O}), 1517(\mathrm{C}=\mathrm{C}), 1106(\mathrm{C}=\mathrm{S}) ;{ }^{1} \mathrm{H}-\mathrm{NMR}$ [DMSO- $d_{6}, 400$ $\mathrm{MHz}$ : ( $\delta, p p m) 7.59\left(\mathrm{~m}, 2 \mathrm{H}, \mathrm{NH}_{2}\right.$, exchanges with $\left.\mathrm{D}_{2} \mathrm{O}\right), 8.00(\mathrm{~m}, 1 \mathrm{H}$, aromatic), 8.13 (s, $1 \mathrm{H}$, olefinic $\mathrm{H}), 8.39$ (m, $3 \mathrm{H}$, aromatic); ${ }^{13} \mathrm{C}-\mathrm{NMR}$ [DMSO- $d_{6}, 100 \mathrm{MHz}$ ]: $(\delta$, ppm) 124.9 (C5-rhodanine), 128.7 - 128.9 (aromatic C), 130.8 (olefinic C), 133.7 - 137.6 (aromatic $\mathrm{C}), 142.7(\mathrm{C}=\mathrm{O}), 178.9(\mathrm{C}=\mathrm{S})$; analysis calculated for $\mathrm{C}_{10} \mathrm{H}_{7} \mathrm{~N}_{3} \mathrm{O}_{3} \mathrm{~S}_{2}: \mathrm{C}, 42.70 ; \mathrm{H}, 2.51 ; \mathrm{N}, 14.94 ; \mathrm{O}, 17.06 ; \mathrm{S}, 22.79$; analysis results: $\mathrm{C}$, $43.01 ; \mathrm{H}, 2.81 ; \mathrm{N}, 15.20 ; \mathrm{S}, 23.09$.

\subsection{Antibacterial Activity}

\subsubsection{Medium and Assay Conditions}

The antibacterial assay was performed using the well diffusion method for all compounds. Mueller Hinton agar (38.0 g of Mueller Hinton agar in $1000 \mathrm{~mL}$ of distilled water) was autoclaved, poured into the Petri dishes, and solidified at $25^{\circ} \mathrm{C}$. The bacteria $\left(10^{6} \mathrm{cells} / \mathrm{mL}\right)$ were transferred to the plates using pipettes and spread on the agar using L-shaped spreaders. For the well diffusion assay, the wells were made in the agar, and each compound was added to individual wells $\left(50 \mu \mathrm{L} /\right.$ well). Plates were incubated at $37^{\circ} \mathrm{C}$ for $24-48 \mathrm{~h}$. The bacterial inhibition was determined by measuring the diameter of the inhibition zone $(\mathrm{mm})$ using a transparent scale. Aliquots of $50 \mu \mathrm{L} /$ well of the comparator antibiotic amoxicillin $(5.0 \mathrm{mg} / \mathrm{mL})$ were used as positive controls.

\subsubsection{Test Microorganisms}

Two Gram-positive bacteria, Staphylococcus aureus (ATCC 25923) and Bacillus subtilis (ATCC 6633), and two Gram-negative bacteria, Escherichia coli (ATCC 25922) and Pseudomonas aeruginosa (ATCC 27853), were used to determine antibacterial activity.

\subsubsection{Minimum Inhibitory Concentration (MIC)}

For performing the MIC assay, the rhodanine compounds were serially diluted in sterile distilled water, and $100 \mu \mathrm{L}$ aliquots of these serial dilutions were added to $900 \mu \mathrm{L}$ sterile nutrient broth. A control test tube containing only nutrient broth medium was used to confirm the sterility of the bacterial culture medium. Aliquots of bacterial suspensions $(10 \mu \mathrm{l})$ containing $10^{5}$ cells $/ \mathrm{mL}$ were used to inoculate the culture tubes, which were incubated at $37^{\circ} \mathrm{C} \pm 1^{\circ} \mathrm{C}$ for $24 \mathrm{~h}$. For MIC determination after $24 \mathrm{~h}$, the test tube with no visible bacterial growth was assigned as the MIC value of the test compound in $\mu \mathrm{g} / \mathrm{mL}$. Each compound was tested in triplicates, and the average of the results was used to derive the MIC value.

\subsubsection{Transmission Electron Microscopy Analysis}

Transmission electron microscopy (TEM) was used to evaluate the morphological changes in E. coli after treatment with compound 3a. Treated bacteria and untreated control bacteria were processed using the same procedure. Upon incubation, the pellets obtained after centrifugation were fixed in Carnovsky's fixative at $25^{\circ} \mathrm{C}$ for $3-4 \mathrm{~h}$ with a mixture containing $2 \%$ paraformaldehyde and 
2.5\% glutaraldehyde. The fixed bacteria were washed three times with $0.1 \mathrm{M}$ phosphate buffer, $\mathrm{pH} 7.2$, for $5 \mathrm{~min}$ and centrifuged at $10,000 \mathrm{rpm}$ in an Eppendorf tube for $15 \mathrm{~min}$. The bacterial pellet was resuspended in $1.0 \mathrm{ml}$ of phosphate buffer and adsorbed on formvar carbon-coated supports, applied as agar 200-mesh copper grids by floating the grids on a drop of the bacterial isolate. The bacteria on the grids were stained by submerging them for $5 \mathrm{~min}$ in $12 \%(\mathrm{w} / \mathrm{v})$ aqueous uranyl acetate and then rinsed with Milli-Q water three times. The grids were examined and photographed using a Philips CM10 transmission electron microscope with an accelerating voltage of $80 \mathrm{kV}$. Images were taken at different magnifications [15] [16] [17].

\subsection{Docking Simulation Studies Using the E. Coli Penicillin-Binding Protein (PBP) 4}

The $E$. coli $\mathrm{PBP} 4$ crystal structure data was obtained from the protein data bank [18] (PDB ID: 2EX8 [19]). The PBP4 structure was corrected via the Molecular Operating Environment (MOE) protein preparation module [20], and all water and ligand molecules were removed. The protein structure data was further processed using the Protein Preparation Wizard [21] [22] in the Maestro software [23] to assign partial charges to each atom according to the optimized potentials for liquid simulations (OPLS) force field and to define the protonation state for each ionizable group. The binding pocket was identified prior to docking using the co-crystallized ligand (penicillin G). Finally, the PBP4 protein was energy-minimized using an RMSD limit of up to $0.3 \AA$. Rhodanine derivatives were built using the MOE [20] and further processed with the LigPrep module [24] in the Maestro program [23] to assign partial charges to all ligand atoms and to generate a single low energy conformation according to the OPLS force field. Then, all ligands were covalently docked into the simulated binding site using the Covalent Docking module [25] in Maestro, employing the pose prediction algorithm for conformational sampling. The reaction type for covalent bonding was set to Michael addition, assuming the reaction of the alkene carbon with the Ser62 hydroxyl group. The pose refinement and scoring steps were used with the default settings. Docked poses were scored by calculating the average of two GlideScore values [26] [27], the docking score "pre-reacted" and the score-in-place "post-reacted" calculation [25]. The GlideScore estimates the binding free energy using multiple terms that includes force field contributions (electrostatic, van der Waals) and terms rewarding or penalizing interactions known to influence ligand binding [27].

\subsection{UV-Vis Measurements}

UV-vis titration was performed by adding aliquots of enzyme solution $(200 \mu \mathrm{L}$; $4.7 \times 10^{-5} \mathrm{M}$ in compound $3 \mathrm{a}$ solution, $5.0 \times 10^{-5} \mathrm{M}$ ) to $2.0 \mathrm{~mL}$ of compound $3 \mathrm{a}$ solution $\left(5.0 \times 10^{-5} \mathrm{M}\right)$. After each addition, the resulted mixture was incubated for $3 \mathrm{~min}$. at room temperature and scanned in the range of $190-700 \mathrm{~nm}$. 


\section{Results and Discussion}

\subsection{Chemistry}

The antimicrobial activity of rhodanines has been known for over 50 years. The design and synthesis of antibacterial drugs containing rhodanine have been described in many studies [28] [29] [30] [31]. The 5-ylidene-4-thiazolidinones and 4-thiazolidinone-3-carboxylic acids are the most studied and promising 4-thiazolidinones in the context of generating new drug-like compounds [32]. Because rhodanine (thiazolidine) moieties appear to be associated with antibacterial activity, we focused our study on the synthesis of new rhodanine derivatives. Thus, to generate new compounds with potentially strong antibacterial activity, we used a basic design as the template (Figure 1) for the synthesis of a new rhodanine derivative series as outlined in Figure 1 and Figure 2.

Compounds 3a-g were synthesized via the Knoevenagel condensation between aldehyde derviative 1 and rhodanine acetic acid 2 . The reaction was carried out in the microwave reactor $\left(100 \mathrm{~W}, 150^{\circ} \mathrm{C}\right)$ in the presence of a catalytic amount of piperidine, which generated the desired products $\mathbf{3 a -} \mathbf{g}$ with a yield of $81 \%-94 \%$ in $2-3$ min (Figure 2 and Table 1).

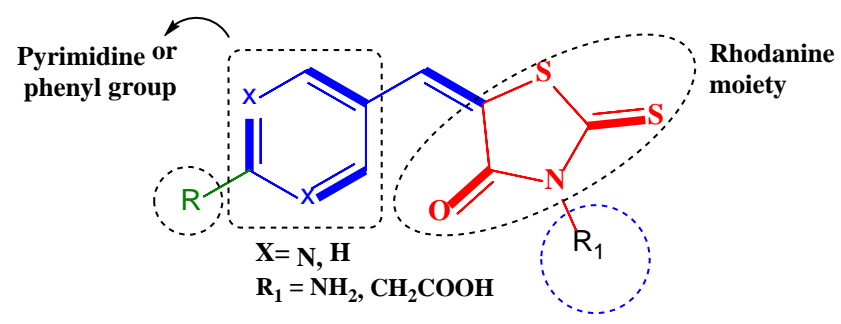

Figure 1. Template design for rhodanine derivatives $\mathbf{3 a - g}$ and $\mathbf{5 a - f}$.<smiles>[R]C=C1SC(=S)N(CC(=O)O)C1=O</smiles>

Figure 2. Synthesis of 5-substituted rhodanine derivatives 3a-g.

Table 1. ${ }^{1} \mathrm{H}$-NMR shifts of the olefinic hydrogen $(\delta, p p m)$ and \% yield of 5 -substituted rhodanine derivatives $3 \mathrm{a}-\mathrm{g}$.

\begin{tabular}{cccc}
\hline Compound No. & $\mathbf{R}$ & Chemical shift $(\boldsymbol{\delta}, \mathrm{ppm})$ & \% Yield \\
\hline 3a & Pyrazolo[1,5-a]pyrimidine & 7.91 & 94 \\
3b & 2-Methoxyphenol & 7.69 & 92 \\
3c & 4-Formylbenzene & 8.00 & 90 \\
3d & 4-Fluorobenzene & 7.81 & 85 \\
3e & $N, N$-Dimethylaminopyrimidine & 7.61 & 81 \\
3f & $N$-Morpholinepyrimidine & 7.64 & 88 \\
3g & Isopropylpyrimidine & 7.62 & 86 \\
\hline
\end{tabular}


The structures of the obtained products were confirmed based on their elemental analysis, along with the following spectral data analysis. The IR spectrum of compound 3a showed characteristic absorption bands at $1723 \mathrm{~cm}^{-1}$ and 1622 $\mathrm{cm}^{-1}$ corresponding to the $\mathrm{C}=\mathrm{O}$ of the carboxylic acid group and the carbonyl group, respectively. The $\mathrm{C}=\mathrm{S}$ group appeared at $1194 \mathrm{~cm}^{-1}$. Another two bands appeared at $1520 \mathrm{~cm}^{-1}$ and $2949 \mathrm{~cm}^{-1}$, which were attributed to $\mathrm{C}=\mathrm{C}$ and $\mathrm{C}-\mathrm{H}$ aliphatic stretching. The ${ }^{1} \mathrm{H}-\mathrm{NMR}$ spectrum identified an olefinic proton resonating at $\delta=7.91 \mathrm{ppm}$, which confirmed the formation of the $Z$-isomer according to published ${ }^{1} \mathrm{H}-\mathrm{NMR}$ data, indicating that the olefinic protons in the $Z$-isomer resonate in the relatively lower field $(\delta>7.30 \mathrm{ppm})$ whereas the olefinic protons in the $E$-form are found in higher field $(\delta<6.80 \mathrm{ppm})$ [33] [34] [35]. In our analysis, the signal appeared at $\delta=12.68 \mathrm{ppm}$, which was exchanged with $\mathrm{D}_{2} \mathrm{O}$ assigned to the hydroxyl group. The singlet appeared at $\delta=8.83 \mathrm{ppm}$ corresponding to the pyrimidine $\mathrm{H}-4,6$ and integrated into two protons. The ${ }^{13} \mathrm{C}-\mathrm{NMR}$ analysis identified the olefinic carbon, which appeared at $\delta=138.1$ ppm. The rhodanine C5 resonated at $\delta=111.8 \mathrm{ppm}$, but the two carbonyl groups appeared at $\delta=167.3$ and $168.5 \mathrm{ppm}$, whereas the $\mathrm{C}=\mathrm{S}$ group resonated at $\delta=$ $193.9 \mathrm{ppm}$.

The synthesis of new arylidene derivatives of 3-aminorhodanine was developed. We demonstrated that the condensation of 3-aminorhodanine with aldehydes in an alcoholic medium generated 3'-arylidene derivatives 5a-f (Figure 3 and Table 2).

Compounds 5a-f were characterized by elemental analyses, along with Fourier-transform infrared spectroscopy (FTIR) and NMR spectroscopy. Both ${ }^{1} \mathrm{H}$ and ${ }^{13} \mathrm{C}$-NMR data were consistent with the predicted structures. The ${ }^{1} \mathrm{H}-\mathrm{NMR}$ data of all derivatives indicated a single olefinic proton, consistent with the formation of a single isomer, which was assigned as $Z$-conformer with the ${ }^{1} \mathrm{H}$-NMR signals for the methine-group hydrogen of the $(Z)$-isomers, which are more downfield than those predicted for the (E)-isomer methine-group. The (Z)-isomers of arylmethylidenerhodanines 5a-f exhibited experimental methine group shifts of $7.67-8.13 \mathrm{ppm}$. The IR spectrum of compound $5 \mathrm{~b}$ showed characteristic absorption bands at $1699 \mathrm{~cm}^{-1}$ corresponding to the $\mathrm{C}=\mathrm{O}$ of the carbonyl group, whereas the $\mathrm{C}=\mathrm{S}$ group signal appeared at $1199 \mathrm{~cm}^{-1}$. The other bands at $3275 \mathrm{~cm}^{-1}$ and $3153 \mathrm{~cm}^{-1}$ were attributed to $\mathrm{NH}_{2}$ groups. The ${ }^{1} \mathrm{H}-\mathrm{NMR}$ spectra for compound $5 \mathrm{~b}$ had the olefinic protons in the very low field of $\delta=$ $7.67 \mathrm{ppm}$, which confirmed the formation of the $Z$-isomer. The signal at $\delta=5.94$

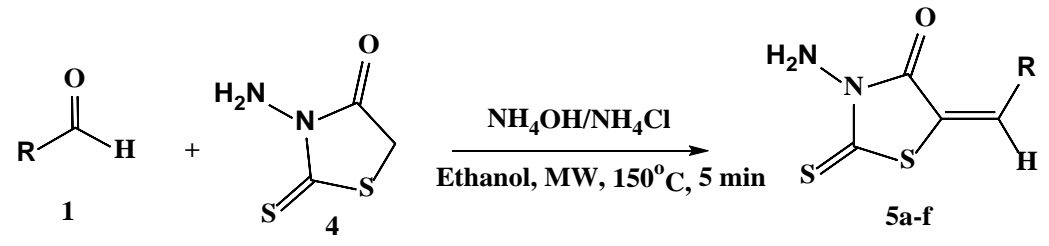

Figure 3. Condensation of 3-aminorhodanine with an aldehyde in alcoholic solution in the presence of $\mathrm{NH}_{4} \mathrm{OH} / \mathrm{NH}_{4} \mathrm{Cl}$ generated rhodanine derivatives $\mathbf{5 a - f}$. 
Table 2. ${ }^{1} \mathrm{H}$-NMR shifts of the olefinic hydrogen $(\delta$, ppm $)$ and \% yield of 5 -substituted rhodanine derivatives $5 \mathrm{a}-\mathrm{f}$.

\begin{tabular}{cccc}
\hline Compound No. & $\mathbf{R}$ & Chemical shift $(\boldsymbol{\delta}, \mathrm{ppm})$ & \% Yield \\
\hline $\mathbf{5 a}$ & Pyrazolo[1,5-a]pyrimidine & 7.97 & 90 \\
$\mathbf{5 b}$ & $N, N$-Dimethylaminopyrimidine & 7.67 & 93 \\
$\mathbf{5 c}$ & Methyl benzoate & 7.68 & 89 \\
$\mathbf{5 d}$ & (E)-Prop-1-en-1-ylbenzene & 7.70 & 91 \\
$\mathbf{5 e}$ & 4-Methoxybenzene & 7.76 & 94 \\
$\mathbf{5 f}$ & 4-Nitrobenzene & 8.13 & 92 \\
\hline
\end{tabular}

ppm indicated the exchanged $\mathrm{D}_{2} \mathrm{O}$ assigned to the amino group. The singlet appeared at $\delta=8.59 \mathrm{ppm}$ corresponding to the pyrimidine $\mathrm{H}-4,6$ and integrated into two protons. The ${ }^{13} \mathrm{C}-\mathrm{NMR}$ identified the olefinic carbon at $\delta=129.9 \mathrm{ppm}$. The rhodanine $\mathrm{C} 5$ resonated at $\delta=115.8 \mathrm{ppm}$, and the carbonyl group appeared at $\delta=160.6 \mathrm{ppm}$ close to the $\mathrm{C}=\mathrm{S}$ group resonating at $\delta=186.8 \mathrm{ppm}$.

\subsection{Biological Studies}

\section{Antimicrobial Activity}

Rhodanine derivatives 3a-d and $\mathbf{5 a - f}$ were assessed for in vitro antibacterial activity against two Gram-positive strains, S. aureus ATCC 25923 and B. subtilis ATCC 6633, and two Gram-negative strains, E. coli ATCC 25922 and $P$. aeruginosa ATCC 27853, using the well diffusion method and including amoxicillin as comparator antibiotic. The MIC results of screening derivatives $3 \mathrm{a}-\mathrm{g}$ and $\mathbf{5 a - f}$ are summarized in Table 3 . The strongest broad-spectrum activity was associated with the derivatives containing the pyrimidine moiety linkage to the rhodanine ring. Out of the two series, 3a-g and 5a-f, compounds $\mathbf{3 a}$ and $\mathbf{5 a}$ exhibited excellent antibacterial activity against Gram-negative bacteria with MICs ranging from 1.12 to $1.5 \mu \mathrm{g} / \mathrm{mL}$. Both compounds, $3 \mathrm{a}(1.12 \mu \mathrm{g} / \mathrm{mL}$ against $E$. coli and $1.25 \mu \mathrm{g} / \mathrm{mL}$ against $P$. aeruginosa) and $5 \mathrm{a}(1.12 \mu \mathrm{g} / \mathrm{mL}$ against $E$. coli and 1.5 $\mu \mathrm{g} / \mathrm{mL}$ against $P$. aeruginosa), were equipotent or more active than amoxicillin $(1.5 \mu \mathrm{g} / \mathrm{mL}$ against $E$. coli and $1 \mu \mathrm{g} / \mathrm{mL}$ against $P$. aeruginosa). The two compounds also showed good activities against the Gram-positive strains. Both compounds, 3a and 5a, had an MIC of $2.5 \mu \mathrm{g} / \mathrm{mL}$ against $S$. aureus and B. subtilis, which was slightly higher than the corresponding amoxicillin MIC $(1.5 \mu \mathrm{g} / \mathrm{mL}$ against $S$. aureus and B. subtilis). Compounds $\mathbf{3 e}$ and $\mathbf{5} \mathbf{b}$ exhibited moderate antibacterial activity against the test organisms (MIC $1.94-11 \mu \mathrm{g} / \mathrm{mL}$ ). However, all other pyrimidine-linked rhodanine derivatives of both series were found to have a good activity profile against both Gram-positive and Gram-negative bacteria, compared to that of amoxicillin. Thus, the in vitro test results for the new pyrimidine analogs $3 \mathrm{a}, 3 \mathrm{e}, 3 \mathrm{f}, 3 \mathrm{~g}, 5 \mathrm{a}$, and $5 \mathrm{~b}$ identified promising antibacterial activity profiles against Gram-positive and Gram-negative bacteria (Table 3, Figure 4). 
A. Abusetta et al.

Table 3. MIC test results of rhodanine derivatives $\mathbf{3 a - g}$ and $\mathbf{5 a - f}$.

\begin{tabular}{|c|c|c|c|c|c|}
\hline \multirow{2}{*}{ Compound ID } & \multirow{2}{*}{ Compounds structure } & \multicolumn{4}{|c|}{$\mathrm{MIC}(\mu \mathrm{g} / \mathrm{mL})$} \\
\hline & & E. coli & $P$. aeruginosa & S. aureus & B. subtilis \\
\hline $3 a$ & & 1.12 & 1.25 & 2.5 & 2.5 \\
\hline $3 b$ & & 6.3 & 12 & 4 & 4 \\
\hline $3 c$ & & 16.2 & 18.1 & 14.3 & 12 \\
\hline $3 \mathrm{~d}$ & & 15.2 & 18 & 7.3 & 4.3 \\
\hline $3 e$ & & 1.94 & 2.5 & 9 & 10 \\
\hline $3 \mathrm{f}$ & & 2.5 & 2.5 & 14.3 & 13 \\
\hline $3 g$ & & 1.6 & 4 & 11.1 & 12 \\
\hline $5 a$ & & 1.12 & 1.5 & 2.5 & 2.5 \\
\hline $5 b$ & & 2 & 2.5 & 9 & 11 \\
\hline $5 c$ & & 16.4 & 15.1 & 10.1 & 11 \\
\hline $5 \mathrm{~d}$ & & 10 & 10 & 10 & 14 \\
\hline $5 e$ & & 9.3 & 15 & 5 & 7.3 \\
\hline $5 f$ & & 18 & 18 & 9 & 13 \\
\hline Amoxicillin & & 1.5 & 1 & 1.5 & 1.5 \\
\hline
\end{tabular}



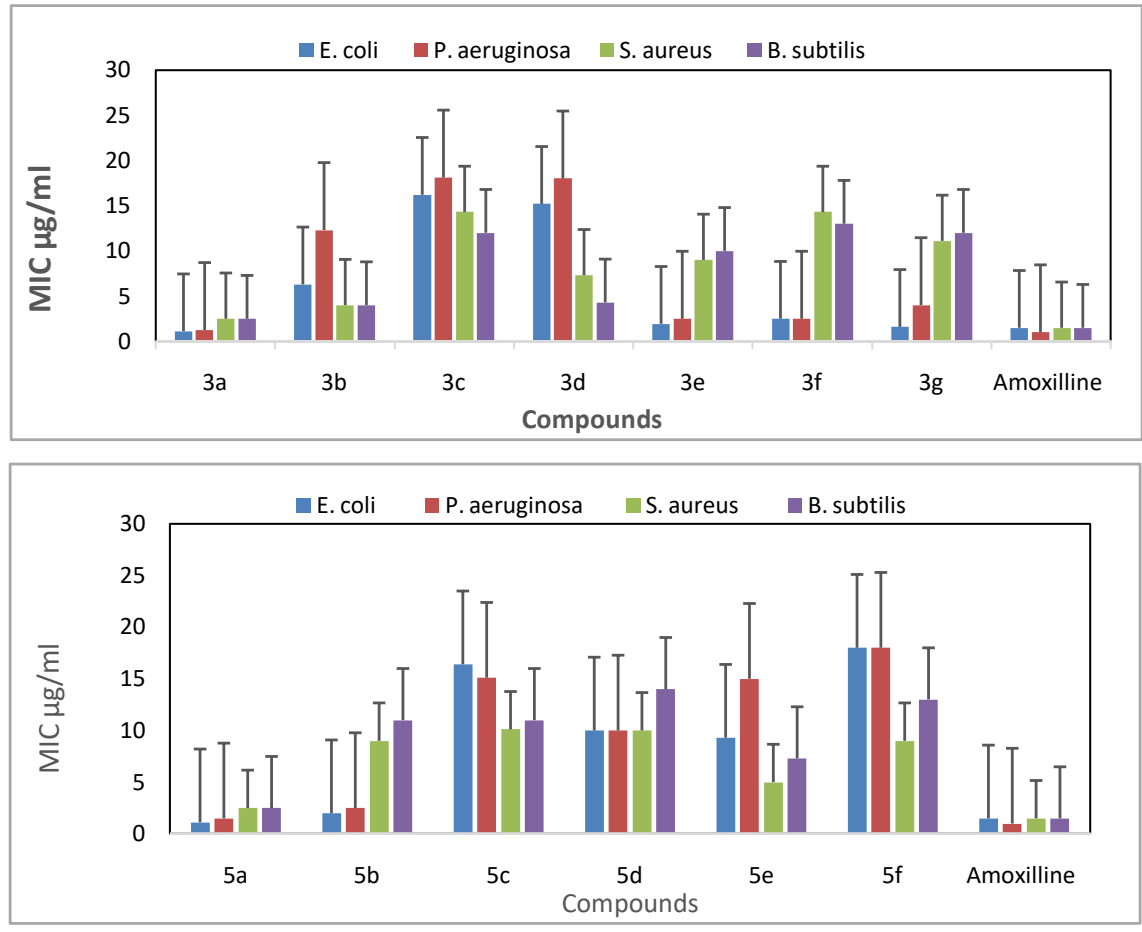

Figure 4. Minimum inhibitory concentrations (MICs, $\mu \mathrm{g} / \mathrm{mL}$ ) of rhodanine derivatives against four representative bacterial strains. MICs of compounds 3a-g (top panel) and 5 a-f (bottom panel) compared with amoxicillin MICs.

The in vitro antibacterial screening results of rhodanine compounds $3 b, 3 c$, $3 \mathrm{~d}, 5 \mathrm{c}, 5 \mathrm{~d}, 5 \mathrm{e}$, and $\mathbf{5 f}$ containing a substituted phenyl group showed that these compounds were more active against the Gram-positive bacteria ( $S$. aureus and $B$. subtilis) than against the Gram-negative bacteria (E. coli and $P$. aeruginosa). However, compound $\mathbf{3 b}$ was also active against $E$. coli and $P$. aeruginosa at MICs of 6.3 and $12 \mu \mathrm{g} / \mathrm{mL}$, respectively. In addition, compound $3 \mathrm{~b}$ exhibited good antibacterial activity against Gram-positive bacteria $S$. aureus and B. subtilis with an MIC of $4 \mu \mathrm{g} / \mathrm{mL}$ (Table 3). Furthermore, the antibacterial screening data indicated that the compounds containing fluoro, methoxy, and hydroxyl groups at para positions, such as $\mathbf{3 d}, \mathbf{5 e}$, and $\mathbf{3 b}$, exerted a good growth inhibition of both Gram-positive test strains (Table 3). Hence, several conclusions can be drawn that are useful in guiding further research. Substitutions on the nitrogen of the rhodanine ring did not appear to have a significant effect on the antibacterial activities of the two most active derivatives ( $\mathbf{3} \mathbf{a}$ and $\mathbf{5 a}$ ), in which the substituent on the rhodanine $\mathrm{C} 5$ was not changed whereas the substituents on the nitrogen were varied, revealing that compounds with amino or N-carboxymethyl substituents on this nitrogen did not significantly differ in their activity. However, our results presented in Table 3 indicated that the linkage of a pyrimidine group to rhodanine generated compounds with higher antibacterial activity than the linkage of a substituted phenyl group to rhodanine. In addition, the screening results and MIC tests showed that rhodanine derivatives containing a pyrimidine moiety were more active toward the Gram-negative bacteria than the 
Gram- positive bacteria. A brief assessment of the structure-activity relationship (SAR) revealed that an electron-donating group substitution at the phenyl ring contributed to a better antibacterial activity.

\subsection{Docking Study}

One of the most predominant bacterial targets for irreversible inhibitors is the PBP. Here we hypothesized that PBP could be a potential target for our newly synthesized rhodanine derivatives. These compounds have an activated double bond that could be attacked by nucleophiles by a common reaction, the Michael addition. The well-characterized catalytic residue of PBP, Ser62, could serve as a nucleophile. Thus, based on the presence of an electrophile in our compounds, we proposed that the rhodanine derivatives could also inhibit PBP by an irreversible mechanism similar to that described for penicillins (Figure 5). Accordingly, the covalent docking of all synthesized ligands into the PBP catalytic pocket was simulated. The predicted docking scores are listed in Table 4. All rhodanine derivatives showed favorable docking scores ranging from -3.8 to -5.1 $\mathrm{kcal} / \mathrm{mol}$ (compared to amoxicillin, $-6.2 \mathrm{kcal} / \mathrm{mol}$ ). The rhodanine-3-carboxylate series showed docking scores ranging from -4.5 to $-5.1 \mathrm{kcal} / \mathrm{mol}$, which is more optimal than the binding energies predicted for the 3-aminorhodanine derivatives $(-3.8$ to $-4.3 \mathrm{kcal} / \mathrm{mol})$. The pyrazolopyrimidine-containing derivative in either series ( $\mathbf{3} \mathbf{a}$ and $\mathbf{5 a}$ ) attained the best docking scores amongst all docked compounds of the same series, which was supported by the MIC testing results (Table 3). The docked poses of compounds $3 \mathrm{a}$ (Figure 6) and $5 \mathrm{a}$ (Figure 7) showed that the pyrazolopyrimidine ring was well-inserted in a hydrophobic region comprising the side chains of Phe160, Leu359, and Leu421, which could explain the superiority of this moiety over all the other tested types. However, the $\mathbf{3 a}$ ligand and other carboxylate derivatives had better docking scores than $\mathbf{5 a}$ and the other of amino derivatives. This was probably associated with the inability of the amino group to make interactions, compared to the capabilities of the carboxylate group, which was heavily involved in ionic interactions and hydrogen bonding with the surrounding basic and polar residues (i.e., Arg402, Arg459, and Ser420). Thus, rhodanine derivatives appear to be able to enter the active site of the target and get oriented (by certain interactions) in a suitable position for the nucleophilic attack by the PBP residue Ser62. Consequently,

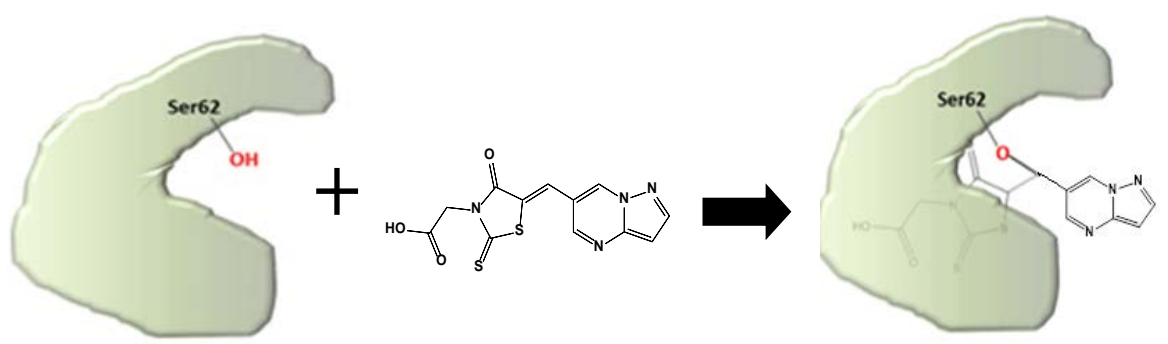

Figure 5. The proposed mechanism of irreversible PBP inhibition by rhodanine derivatives by Michael addition. 
Table 4. Docking scores of rhodanine derivatives covalently bound to the PBP active site.

\begin{tabular}{cccc}
\hline Compound ID & $\begin{array}{c}\text { Docking affinity } \\
(\mathbf{k c a l} / \mathrm{mol})\end{array}$ & Compound ID & $\begin{array}{c}\text { Docking affinity } \\
(\mathrm{kcal} / \mathrm{mol})\end{array}$ \\
\hline 3a & -5.13 & $\mathbf{5 a}$ & -4.18 \\
3c & -4.90 & $\mathbf{5 b}$ & -3.98 \\
3b & -4.54 & $\mathbf{5 c}$ & -3.94 \\
3d & -4.83 & $\mathbf{5 d}$ & -4.30 \\
3e & -4.63 & $\mathbf{5 e}$ & -4.09 \\
3f & -4.54 & $\mathbf{5 f}$ & -3.82 \\
3g & -4.91 & Amoxicillin & -6.2 \\
\hline
\end{tabular}
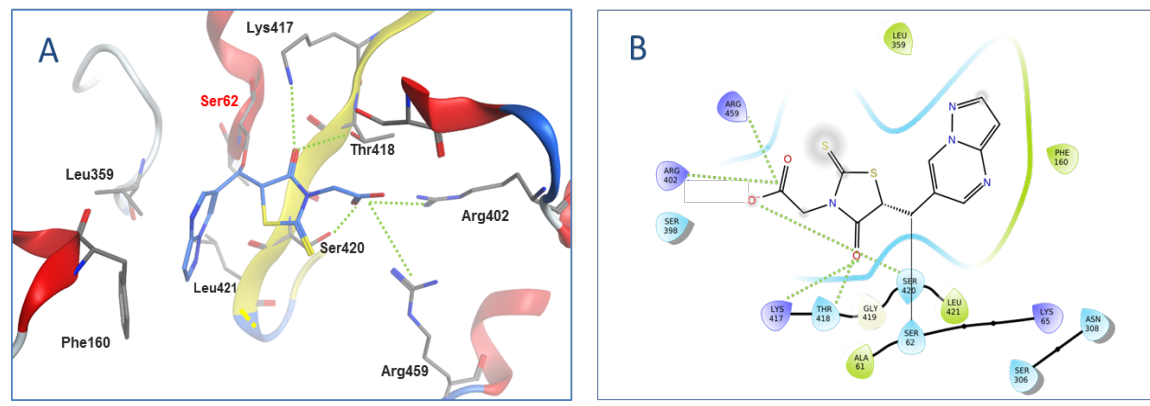

Figure 6. Binding of $\mathbf{3 a}$ to PBP. The $\mathbf{3 a}$ binding pose (blue sticks) predicted to bind to PBP (ribbon and gray sticks) (A) along with the 2D binding diagram (B). The nucleophilic residue is labeled in red color and the hydrogen bonds are depicted as green dotted lines.
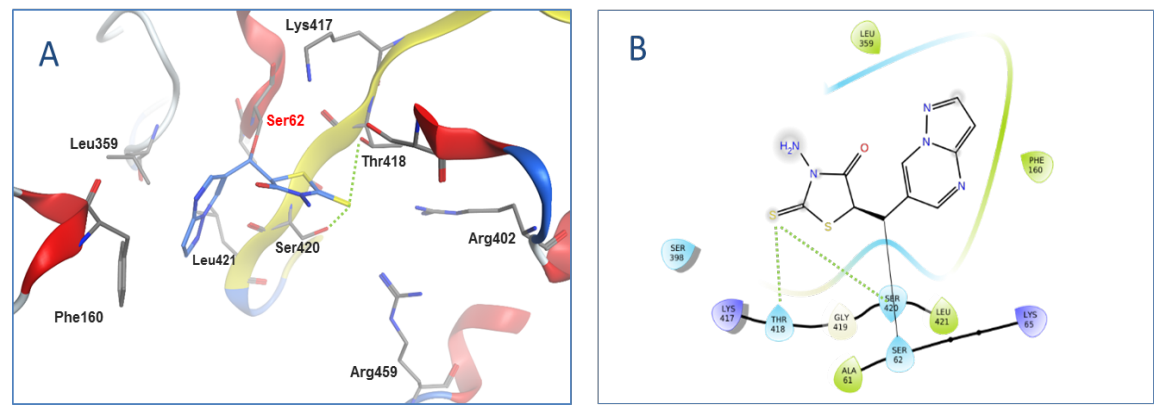

Figure 7. Binding of $\mathbf{5} \mathbf{a}$ to PBP. The $\mathbf{5 a}$ binding pose (blue sticks) predicted to bind to PBP (ribbon and gray sticks) (A) along with the 2D binding diagram (B). The nucleophilic residue is labeled in red color and the hydrogen bonds are depicted as green dotted lines.

the enzyme is irreversibly inhibited, resulting in the inhibition of the cell wall synthesis and leading to the death of bacterial cells.

\subsection{Morphological Changes of E. Coli Cells in the Presence of Compound 3a}

The morphological changes observed using TEM provided evidence for interactions with the cell wall, leading ultimately to cell wall disruption. For instance, 
PBP located in the cytoplasmic membrane could bind to compound $\mathbf{3 a}$ and change the cell morphology as a result of this PBP-compound 3a interaction. In addition, untreated cells were studied by TEM as controls (untreated bacteria) to confirm the observed irregularities in bacterial cells exposed to compound 3a. The TEM analysis of untreated bacteria showed normal external morphological features of the cells. E. coli cells diluted in phosphate buffer had many filaments, such as flagella and fimbriae (Figure 8(a)-(c)). The fimbriae were approximately $7.00 \mathrm{~nm}$ wide, and up to $900 \mathrm{~nm}$ long. In contrast, after treatment with compound $3 \mathrm{a}$ for $2 \mathrm{~h}$, the bacterial cells appeared to be severely damaged (Figure 8 (d)-(f)). The cells had an unusual morphology with a cracked and ruptured cell envelope. Electron-dense particles or precipitates were also observed around the damaged bacterial cells. Moreover, the damaged cells showed either localized or complete separation of the cell membrane from the cell wall. The cellular degradation was also indicated by electron-translucent cytoplasm and general cellular disruptions within the damaged cells. These findings supported the hypothesis that rhodanine compound $3 \mathrm{a}$ could exert its antibacterial activity by inhibiting the PBP activity, which is essential for bacterial cell wall synthesis.

\subsection{UV-Vis Study}

UV-vis absorption technique used to confirm the structural alteration in an enzyme and to detect complex formation. In the binding experiment, UV-vis absorption spectroscopy was implemented to investigate the binding effect between the $\beta$-lactamase enzyme and the compound 3a. The band at $238 \mathrm{~nm}$ was attributed to the $\mathrm{n}-\sigma^{*}$, while the band at $297 \mathrm{~nm}$ appeared to be a combination of $\mathrm{n}-\pi^{*}$ and $\pi-\pi^{*}$ transitions. The $\beta$-lactamase enzyme band is at $261 \mathrm{~nm}$. The enzyme band at $261 \mathrm{~nm}$ broadly overlapped with the two weak bands of the compound 3a, which made it difficult to deduce the complex formation. However, the band of compound at $417 \mathrm{~nm}$ is out of the absorption range of the enzyme. Therefore, the increase in the intensity of this band upon the addition of the enzyme suggests the interaction between the enzyme and the compound $\mathbf{3 a}$ (Figure 9).

\section{Conclusion}

Two new series of rhodanine derivatives, $\mathbf{3 a - g}$ and $\mathbf{5}$ a-f, were designed and synthesized. The structures of the synthetic products were confirmed using elemental analysis and spectroscopic techniques. The synthetic compounds were screened for antibacterial activities against four pathogenic bacteria. According to the in vitro testing results, some of the new synthetic rhodanine derivatives exhibited strong pharmacological effects. The broadest antibacterial activities were observed with compounds $3 \mathbf{a}$ and $5 \mathbf{a}$ containing a pyrazolopyrimidine moiety. These compounds had MIC values in the range of $1.12-2.5 \mu \mathrm{g} / \mathrm{mL}$. Interestingly, rhodanine derivatives containing pyrimidine were more effective toward Gram-negative bacteria than Gram-positive bacteria. To confirm the results obtained from the in-vitro antimicrobial and docking studies, the interactions 


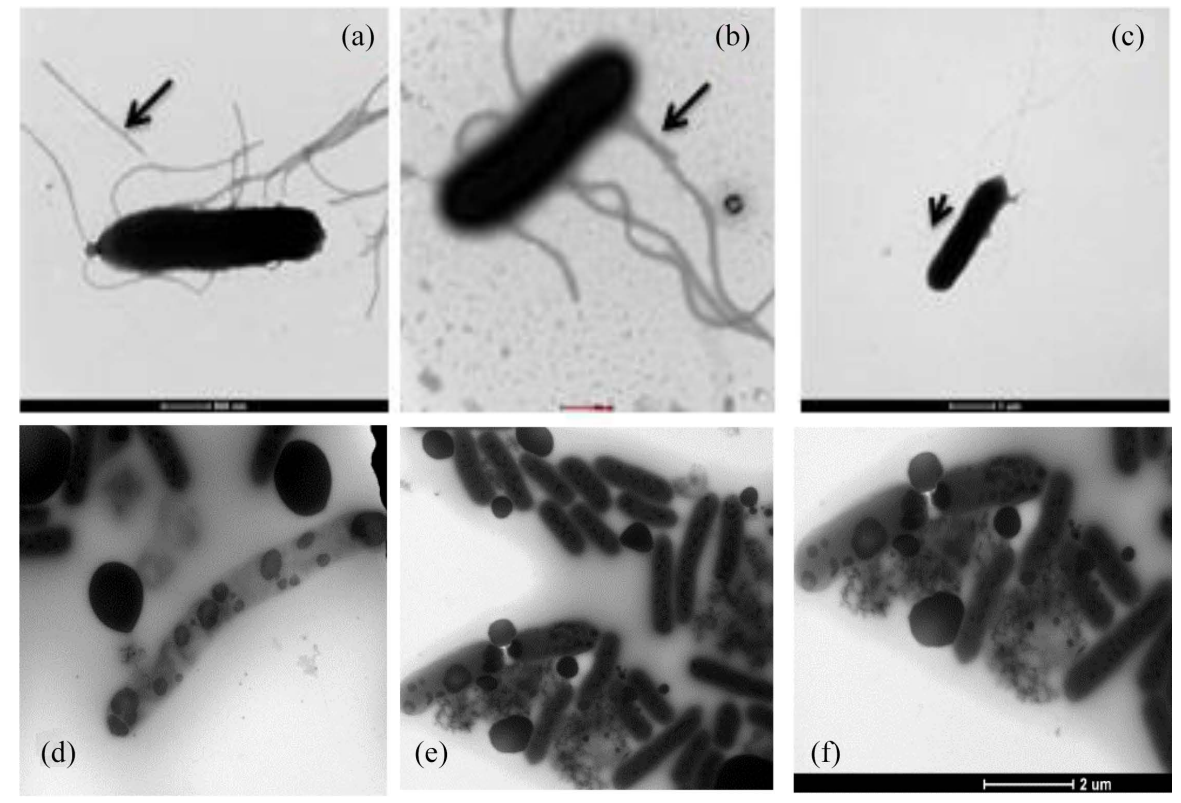

Figure 8. External morphology of unstained E. coli cells observed by TEM. (a)-(c) Untreated $E$. coli cells; an arrow and an arrowhead indicate fimbriae and a flagellum, respectively. (d)-(f) E. coli cells treated with 3 a solution (0.2 ppm).

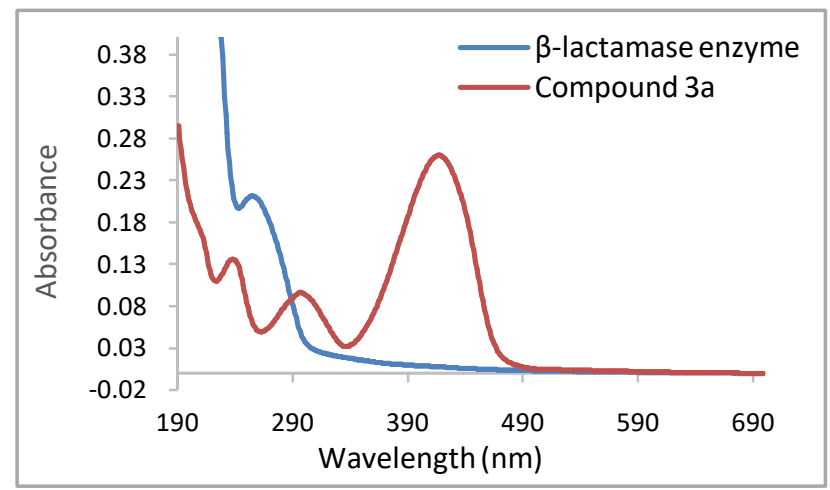

(a)

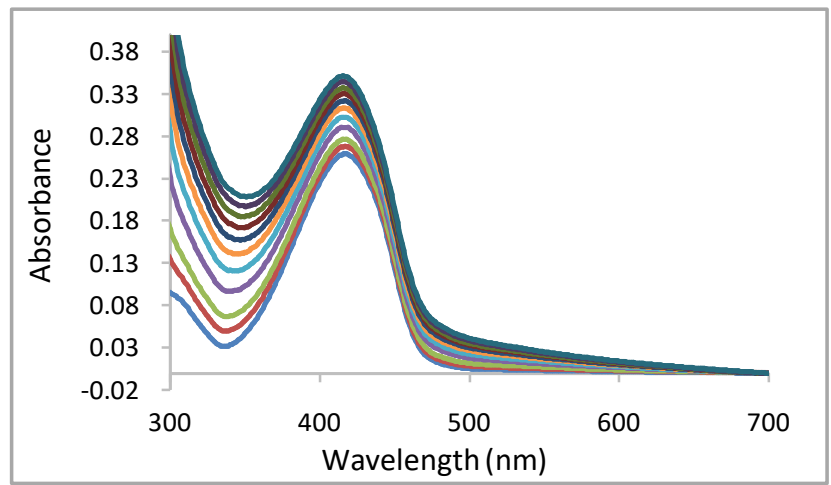

(b)

Figure 9. (a) Absorbance spectra of compound 3a $\left(5 \times 10^{-5}\right.$ $\mathrm{M})$, and $\beta$-lactamase enzyme $\left(2.2 \times 10^{-6} \mathrm{M}\right)$ in buffer $\mathrm{pH} 7.4$; (b) UV-vis absorption titration of compound $3 \mathrm{a}$ against the $\beta$-lactamase enzyme. 
between the compound $3 \mathbf{a}$ and the $\beta$-lactamase enzyme were investigated using UV-vis, which suggests the interaction between the enzyme and the compound 3a. Thus, our study provided valuable evidence that the new synthetic rhodanine compounds displayed a significant potential to be tested as novel therapeutics for the treatment of bacterial infections.

\section{Acknowledgements}

The authors wish to acknowledge the significant financial support of UAE University, Research Affairs Sector (grant no. SURE 1046).

\section{Conflicts of Interest}

The authors declare no conflicts of interest regarding the publication of this paper.

\section{References}

[1] Chopra, I., et al. (2008) Treatment of Health-Care-Associated Infections Caused by Gram-Negative Bacteria: A Consensus Statement. The Lancet Infectious Diseases, 8, 133-139. https://doi.org/10.1016/S1473-3099(08)70018-5

[2] Overbye, K.M. and Barrett, J.F. (2005) Antibiotics: Where Did We Go Wrong? Drug Discovery Today, 10, 45-52. https://doi.org/10.1016/S1359-6446(04)03285-4

[3] Rossolini, G.M.A., Pecile, P. and Pollini, S. (2014) Update on the Antibiotic Resistance Crisis. Current Opinion in Pharmacology, 18, 56-60.

https://doi.org/10.1016/j.coph.2014.09.006

[4] Moellering, R.C. (2008) Current Treatment Options for Community-Acquired Methicillin-Resistant Staphylococcus aureus Infection. Clinical Infectious Diseases, 46, 1032-1037. https://doi.org/10.1086/529445

[5] Liu, J.C., et al. (2014) Synthesis and Evaluation of the Antimicrobial Activities of 3-((5-phenyl-1,3,4-oxadiazol-2-yl)methyl)-2-thioxothiazolidin-4-one Derivatives. European Journal of Medicinal Chemistry, 74, 405-410. https://doi.org/10.1016/j.ejmech.2013.12.054

[6] Schemmel, K.E., Padiyara, R.S. and D’Souza, J.J. (2010) Aldose Reductase Inhibitors in the Treatment of Diabetic Peripheral Neuropathy: A Review. Journal of Diabetes and Its Complications, 24, 354-360. https://doi.org/10.1016/j.jdiacomp.2009.07.005

[7] Cutshall, N.S., O’Day, C. and Prezhdo, M. (2005) Rhodanine Derivatives as Inhibitors of JSP-1. Bioorganic \& Medicinal Chemistry Letters, 15, 3374-3379.

https://doi.org/10.1016/j.bmcl.2005.05.034

[8] Alegaon, S.G., et al. (2012) Novel Imidazo[2,1-b][1,3,4]thiadiazole Carrying Rhodanine-3-acetic Acid as Potential Antitubercular Agents. Bioorganic \& Medicinal Chemistry Letters, 22, 1917-1921. https://doi.org/10.1016/j.bmcl.2012.01.052

[9] Azizmohammadi, M., et al. (2013) 2H-chromene Derivatives Bearing Thiazolidine2,4-dione, Rhodanine or Hydantoin Moieties as Potential Anticancer Agents. European Journal of Medicinal Chemistry, 59, 15-22. https://doi.org/10.1016/j.ejmech.2012.10.044

[10] Rajamaki, S., et al. (2009) Exploration of Novel Thiobarbituric Acid-, Rhodanineand Thiohydantoin-Based HIV-1 Integrase Inhibitors. Bioorganic \& Medicinal Chemistry Letters, 19, 3615-3618. https://doi.org/10.1016/j.bmcl.2009.04.132 
[11] Kumar, G., et al. (2007) Discovery of a Rhodanine Class of Compounds as Inhibitors of Plasmodium falciparum Enoyl-Acyl Carrier Protein Reductase. Journal of Medicinal Chemistry, 50, 2665-2675. https://doi.org/10.1021/jm061257w

[12] Ergenc, N., et al. (1999) Synthesis and Hypnotic Activity of New 4-Thiazolidinone and 2-thioxo-4,5-imidazolidinedione Derivatives. Archiv der Pharmazie ( Weinheim), 332, 343-347. https://doi.org/10.1002/(SICI)1521-4184(199910)332:10<343::AID-ARDP343>3.0.C $\underline{\mathrm{O} ; 2-0}$

[13] Rauter, A.P., et al. (2005) Bioactive Pseudo-C-Nucleosides Containing Thiazole, Thiazolidinone, and Tetrazole Rings. Journal of Carbohydrate Chemistry, 24, 275-296. https://doi.org/10.1081/CAR-200060396

[14] Gollapalli Naga Raju, K.B.S., et al. (2015) Synthesis, Characterization and Antimicrobial Evaluation of Some Azole Derivatives. World Journal of Pharmacy and Pharmaceutical Sciences, 4, 865-875.

[15] Sjostrand, F.S. (1956) A Method to Improve Contrast in High Resolution Electron Microscopy of Ultrathin Tissue Sections. Experimental Cell Research, 10, 657-664. https://doi.org/10.1016/0014-4827(56)90043-X

[16] Reynolds, E.S. (1963) The Use of Lead Citrate at High pH as an Electron-Opaque Stain in electron Microscopy. Journal of Cell Biology, 17, 208-212. https://doi.org/10.1083/jcb.17.1.208

[17] Karnovsky, M.J. (1965) A Formaldehyde-Glutaraldehyde Fixative of High Osmolarity for Use in Electron Microscopy. Journal of Cell Biology, 27, 137.

[18] Protein Data Bank. http://www.pdb.org

[19] Kishida, H., Roper, D.I., Lloyd, A., Park, S.-Y. and Tame, J.R.H. (2006) Crystal Structure of Penicillin Binding Protein 4 (dacB) from Escherichia coli, Both in the Native Form and Covalently Linked to Various Antibiotics. Biochemistry, 45, 783-792. https://doi.org/10.1021/bi051533t

[20] Molecular Operating Environment (MOE) (2009). http://www.chemcomp.com

[21] Schrödinger Release 2015-2: Schrödinger Suite 2015-2 Protein Preparation Wizard; Epik Version 3.2, S., LLC, New York, NY, 2015; Impact Version 6.7, Schrödinger, LLC, New York, NY, 2015; Prime Version 4.0, Schrödinger, LLC, New York, NY, 2015.

[22] Madhavi Sastry, G.A., Day, T., Annabhimoju, R. and Sherman, W. (2013) Protein and Ligand Preparation: Parameters, Protocols, and Influence on Virtual Screening Enrichments. Journal of Computer-Aided Molecular Design, 27, 221-234. https://doi.org/10.1007/s10822-013-9644-8

[23] Maestro 9.9.013, S., LLC: 101 SW Main Street, Suite 1300, Portland, OR, USA. http://www.schrodinger.com

[24] Schrödinger Release 2015-2: LigPrep, v., Schrödinger, LLC, New York, NY, 2015.

[25] Zhu, K.B., Greenwood, J.R., Day, T., Abel, R., Farid, R.S. and Harder, E. (2014) Docking Covalent Inhibitors: A Parameter Free Approach to Pose Prediction and Scoring. Journal of Chemical Information and Modeling, 54, 1932-1940. https://doi.org/10.1021/ci500118s

[26] Small-Molecule Drug Discovery Suite 2015-2: Glide, v., Schrödinger, LLC, New York, NY, 2015.

[27] Halgren, T.A.M., Friesner, R.A., Beard, H.S., Frye, L.L., Pollard, W.T. and Banks, 
J.L. (2004) Glide: A New Approach for Rapid, Accurate Docking and Scoring. 2. Enrichment Factors in Database Screening. Journal of Medicinal Chemistry, 47, 1750-1759. https://doi.org/10.1021/jm030644s

[28] Pardasani, R.T., Sherry, D., Chaturvedi, V., et al. (2001) Synthetic and Antibacterial Studies of Rhodanine Derivatives with Indol-2,3-diones. Indian Journal of Chemistry, 40, 1275-1278.

[29] Grant, E.B., et al. (2000) The Synthesis and SAR of Rhodanines as Novel Class C Beta-Lactamase Inhibitors. Bioorganic \& Medicinal Chemistry Letters, 10, 2179-2182. https://doi.org/10.1016/S0960-894X(00)00444-3

[30] Tejchman, W., et al. (2017) Antibacterial Properties of 5-Substituted Derivatives of Rhodanine-3-Carboxyalkyl Acids. Medicinal Chemistry Research, 26, 1316-1324. https://doi.org/10.1007/s00044-017-1852-7

[31] Tomasic, T. and Peterlin Masic, L. (2012) Rhodanine as a Scaffold in Drug Discovery: A Critical Review of Its Biological Activities and Mechanisms of Target Modulation. Expert Opinion on Drug Discovery, 7, 549-560. https://doi.org/10.1517/17460441.2012.688743

[32] Metwally, N.H. (2014) A Simple Green Synthesis of (Z)-5-arylmethylene-4-thioxothiazolidines and Thiopyrano[2,3-d]thiazolidine-2-thiones in PEG-400 under Catalyst-Free Conditions. Journal of Sulfur Chemistry, 35, 528-537. https://doi.org/10.1080/17415993.2014.933341

[33] Sing, W.T.L., Yeo, S.L., Lim, S.P., Sim, M.M., et al. (2001) Arylalkylidene Rhodanine with Bulky and Hydrophobic Functional Group as Selective HCV NS3 Protease Inhibitor. Bioorganic \& Medicinal Chemistry Letters, 11, 91-94. https://doi.org/10.1016/S0960-894X(00)00610-7

[34] Khodair, A.I. (2000) A Convenient Synthesis of 2-arylidene-5H-thiazolo[2,3-b]quinazoline-3,5[2H]-diones and Their Benzoquinazoline Derivatives. Journal of Heterocyclic Chemistry, 39, 1153-1160. https://doi.org/10.1002/jhet.5570390607

[35] Ohishi, Y.M., Nagahara, M., Yajima, M., Kajikawa, N., Miahara, K., Takano, T., et al. (1990) Preparations of 5-alkylmethylidene-3-carboxymethylrhodanine Derivatives and Their Aldose Reductase Inhibitory Activity. Chemical and Pharmaceutical Bulletin, 39, 1911-1919. https://doi.org/10.1248/cpb.38.1911 